\title{
The Role of Counseling Guidance Teacher for Helping Self Adjustment of Special Needs Children in Inclusion School
}

\author{
Ana Rafikayati, Lutfi Isni Badian \\ Special Education Department, \\ Universitas of PGRI Adi Buana Surabaya \\ Surabaya, Indonesia \\ ana.rafikayati@gmail.com, lutfiisnibadiah@gmail.com
}

\author{
Boy Soedarmadji \\ Conseling and Guidance Department, \\ University of PGRI Adi Buana Surabaya \\ Surabaya, Indonesia \\ mudhar.bps@gmail.com
}

\begin{abstract}
Self-adjustment is an important aspect of someone's life. Individual who can adjust themselves well will get happiness, independence and harmony within themselves and their environment. Unfortunately, not all children with special needs can adapt themselves well to their environment, especially in inclusive schools. The limitations of experiences make her/him difficult to adjust. As a result, children with special needs actually withdraw themselves from their environment, feeling unhappy, and bullied by their friends make them vulnerable. Therefore, children with special needs require help to adjust in school and help them to participate in the community. In the article will discuss the role of teachers in inclusion schools to help children with special needs adjust in school so that they can be accepted in the school and community.
\end{abstract} teacher.

Keywords-Self adjustment; children with special needs;

\section{INTRODUCTION}

Adaptation is a continuous of personal and interpersonal interaction. Self-adjustment means an effort to change one's self in order to match environment and change environment in order to match one's self [1]. Adjustment by changing yourself according to the environment is also called autoplastic (auto means itself, plastic means formed). Meanwhile, adjusting to changing the environment in accordance with the self-desire is called or alloplastic (which means the others)

The development of individual life, especially children with special needs, influenced by their self-adjustment. In general, children with special needs is defined as a child who experiences the learning process due to physical barriers, mental disorders, emotional disorders, social and communication disorders, and or has special intelligence and talents. Those obstacles experienced by children with special needs, makes them difficult in adjusting to both the school and the community environment. Children with special needs with various characteristics of needs often find themselves facing obstacles in adjusting themselves both in school and in the community. Children with special needs have a higher risk of adjustment barriers compared to normal children [2].
Nowadays, there is an inclusive education that enables children with special needs to study in regular schools along with normal children. In Regulation of The Minister Education Number 70 of 2009 which regulates the implementation of inclusive education, stated that students who have abnormalities and have physical, emotional, mental, social, and /or have intellectual potential and /or special talents need to get education services that can be held inclusive. It is expected that inclusive education can provide the education that appropriate for children with special needs.

The adjustment of the children with special needs arising problems in the implementation of inclusive education. The problems experienced by the children with special needs, are they feel over-shadowed by normal children, feeling awkward in class, difficult to get friends when playing, and not being considered in school. In addition, the quiet nature possessed by student with special needs can also make it difficult for them to adjust to their peers, they prefer to be alone rather than join normal children because they feel afraid of being teased by their friends.

This is supported by Adwisa [3] which reveals that students with special needs who attend inclusive schools have lower adaptive abilities than students with special needs who attend special schools. The low adjustment ability is due to competition in inclusive schools owned by students with special needs. So it causes problems of self-adjustment within students with special needs. In inclusive schools, students with special needs tend to try to imitate normal students so they are easily to feeling depressed and frustrated [4].

In addition, Foster also describes that students with special needs who are in inclusive schools tend to experience loneliness, feel isolated from the environment and accept rejection [5]. It revealed that students with special needs have good self-adjustment when they are in special schools for children with special needs; this is because they feel comfortable to interact with their fellow students [6].

A good self-adjustment can help children with special needs able to develop strong and positive friendship, succeed in school, and successfully exploring the role of adults such as 
employees, coworkers/co-workers, and community members. A good self-adjustment also supports the positive development of healthy adult relationships with family members and peers. Based on the problems regarding the conformity of the children with special needs above, it is necessary to intervene in counseling and guidance from teachers in inclusive schools. Social personal guidance services are directed to assist children with special needs so that they can adjust to all aspects of daily life. Of course, providing of this social personal guidance service needs adjusts to the conditions, disturbances and characteristics of each student with special needs.

\section{METHOD}

This article was the review of literature. The approach is to state a general purpose or question so that views of the participants will emerge [7].

\section{RESULT AND DISSCUSSION}

\section{A. Problems of Self-Adjustment for Children with Special Needs}

Adaptation is a process that includes mental and behavioral responses, where individuals try to overcome their inner needs, relieve the tension, conflict, and frustration they experience so that harmony between the demands of themselves and the environment in which they live [8]. Self-adjustment is an individual's ability to react because of demands in meeting needs and achieving inner peace in relation to the surrounding environment [9].

There are several aspects of self-adjustment that must be met by an individual [10] including:

\section{1) Self-Adjustment}

This adjustment is an individual's acceptance of himself, concerning conflict, pressure, and circumstances in an individual, both physical and psychological. This is also influenced by attitudes and perceptions of one self's and the environment. There are some children with special needs who are those still cannot accept their disability consciously. Especially for disabilities that are acquired after birth, there is a tendency for those who receive disability after birth to have difficulty in adjusting themselves and knowing a greater selfconcept than children with special needs who received their disability from birth.

\section{2) Social-Adjustment}

Social adjustment occurs within the scope of the social relationship in which the individual lives and interacts. In society there are norms, rules, laws, customs and values that must be obeyed by every member of the community. Community members are also required to be able to adjust to the existing conditions. Children with special needs not only faced a negative stigma, which will only be a burden on the community, but also faced problems regarding accessibility. Limited accessibility in the community is an inhibiting factor for them to participate, socialize and adapt to the community

According to Schneiders in [11], self-adjustment is viewed from several perspectives, namely: (1) self-adjustment as an adaptation, (2) adjustment as a form of conformity, (3) self- adjustment as a mastery business. There are three types of adjustment [9], including:

- family adjustment

- social adjustment

- school adjustment

Children with special needs have difficulty in making adjustment within themselves, school and their environment. They faced various problems according to the disability. Meadow said that deaf children who experience language disorders, they encounter problems in communication that have an impact on their adjustment [12].

Likewise, children have difficulty learning to face the problems of adjustment due to their specificity. Children with learning difficulties have emotional, psychological and social problems that make them vulnerable to anxiety, depression, behavioral disorders, feelings of inferiority and social isolation. Research conducted by [13], showed children with learning difficulties even experienced difficulties during the transition period from elementary school to junior high school. They feel isolated, lack of skills and adaptation, and have a bad relationship with the teacher.

Children with visual impairment are also having psychological problems and self-adjustment. They also have problems in orientation and mobility, problems in social relations, problems in conversation, and even suffer from a variety of psychological problems due to disabilities which include: refusal or not being able to accept themselves with disabilities, experiencing feelings of bitterness, feeling inferior to normal people, and experience anxiety and depression [14].

Every parent wants their children to be happy successful in his life and community. According to [15] there are several factors that can influence self-adjustment, including:

\section{1) Condition of the child}

Children who have a difficult temper are easily hurt psychologically, tend to be afraid and shy in facing new stimuli than children who are friendly and open to the social environment. This condition causes their opportunity to interact and adapt to a reduced social environment.

\section{2) Interaction with environment}

Children learning to develop social skills including selfadjustment are from the process of modeling (imitation) of the behavior of parents and peers. Therefore parents, friends, and teachers must certainly be able to provide opportunities for children with special need to establish contacts or interact with the environment, and motivate the children with special need to be socially active. This is expected to lead to good social adjustment.

From the explanation above, it is known that the environment plays an important role in children with special need's adaptability. In a family environment, parents become important figures who can grow their children's social skills. Whereas in the school environment; teachers, especially guidance and counseling teachers and peers also play a role in developing students' social skills. 


\section{B. The Role of Counseling Guidance Teachers to Increasing Self-Adjustment Children With Special Need}

Guidance and counseling teachers have full duties, responsibilities and authority in the process of guidance and counseling services. Counseling guidance service is an assistance provided to someone so that it can help solve the problem [16]. In the activities of guidance and counseling services aim to help all students/students without any exception, not only normal children but also children with special needs to find their own identity and grow optimally.

Guidance and counseling service in inclusive schools is focused on activities to help children with special needs to find self-concept, facilitating adjustment to overcome the obstacles, collaborating with experts from various backgrounds, conducting counseling with children with special need's families, to have social and personal skills, to be able to live independently and to be able to develop his hobby, helping the development of children with special needs to be maximal. One of the developments that must be achieved by children with special needs is social development where they must be able to interact and socialize with their environment according to their social development [17].

The guidance and counseling teacher is expected to help and provide services that are appropriate for children with special needs in order to help to accept their conditions consciously and find specific needs according to their characteristics. Guidance and counseling services can provide career aspect, learning aspect, personal and social aspects in order to get along and socialize. There are several efforts that can be done by the guidance and counseling teacher in assisting the adjustment of children with special needs in terms of learning activities and interaction with peers [18] including:

1) Teacher's efforts in assisting in the adjustment of children with special needs in learning activities

- Conducting learning skills development

- Guiding for develop learning skills

- Guiding to use learning facilities and infrastructure effectively

- Guiding to know his/herself

- Guiding to know and utilize the learning environment

- Guiding study groups

2) The Teacher's Efforts To Help adjustment Children with Special Needs With Peers

- Providing opportunities to participate in social activities

- Guiding children with special needs to be able to accept disability

- Directing children with special needs in organizing a better future life

- Instilling confidence in students with special needs

In line with [15], guidance and counseling teacher has important role in developing social skills of children with special needs, such as:

\section{1) Leader}

Guidance and counseling teachers are leaders in the development of guidance and counseling services that are part of a comprehensive counseling and guidance program.

\section{2) Initiator}

The guidance and counseling teacher is expected to take the initiative in the development of social skills of children with special needs through needs analysis

\section{3) Facilitator}

Guidance and counseling teacher should be able to provide facilities for children with special needs when needing assistance by providing orientation services, information services, individual counseling, consultation, mediation services and advocacy services

\section{4) Consultant}

As a consultant, the task of guidance and counseling teacher is not only as a consultant for children with special needs, but also normal students, other teachers and even parents when have difficulties in helping children with special needs to adapt.

\section{5) Model}

As explained earlier, that children with special needs learn social skills and adaptation by imitating from those around them, including guidance and counseling teachers. Therefore, guidance and counseling teachers should be able to become models or figures in fostering social skills.

\section{CONCLUSION}

It is undeniable that children with special needs have various problems in their lives due to their disabilities. These problems vary according to their specific characteristics. Inclusive education is an education system that allows children with special needs to learn with normal children in regular schools. However, children with special needs also have problems in terms of adjustment. Children with special needs often faced difficulties in adjusting themselves when at school. This is where the role of guidance and counseling teacher important so that children with special needs can consciously accept their condition and find needs that are consistent with their characteristics. Guidance and counseling services can also prepare students' career aspect, learning aspect, personal and social aspects in order to socialize. Guidance and counseling services in inclusive schools is focused on activities to help children with special needs to find self-concept, facilitate selfadjustment, coordinate with experts from various backgrounds, conduct counseling with children with special need families, have social and personal skills, be able to live independently and be able to develop his hobby, help the development of children with special need to be maximal. Counselors have an important role in developing children with special need's social skills, including being a leader, initiator, facilitator, consultant, model. There are several efforts that can be done by the guidance and counseling teacher, including developing learning skills, guiding to have learning skills, guiding to using learning facilities and infrastructure effectively, guiding to knowing her/his self, guiding to recognize and utilizing the learning environment, guiding learning groups, provide 
opportunities to provide opportunities to participate in social activities, guide children with special needs to accept disability, guiding children with special needs in managing a better future life, and give confidence in student with special needs.

\section{REFERENCES}

[1] G. Gerungan. Psikologi sosial, Bandung: Refika Aditama, 2004.

[2] S. Sataphy, "Psychosocial and demographic correlates of academic performance og hearing impaired adolescents," Journal of Asia Pacific Disability Rehabilitation, pp. 63-75, 2008

[3] N. Dwisa, "Perbedaan penyesuaian diri antara siswa tunarungu di sekolah inklusi dan di sekolah luar biasa," Jurnal Psikologi Pendidikan dan Perkembangan, vol. 2, no. 1, 2013.

[4] J. Madhubala, Adjustment Problem of Hearing Impaired, New Delhi: Discovery Publishing House, 2010.

[5] M. Stinson, and H. Lang, The potential impact on deaf students of the full inclusion movement, Conference of Educational Administrators Serving The Deaf and the Gallaudet Research Institute, Washington DC: Gallaudet Research Institute, 1994

[6] I. Leigh, Psychosocial implications of FUll inclusion for deaf children and adolescents, Conference of Educational Administrators Serving the Deaf and the Gallaudet Research Institute, Washington, D.C.: Gallaudet Research Institute, 1994.

[7] J. W. Creswell, Educational Research, Boston: Pearson Education, Inc, 2012.

[8] D. Desmita, Pskologi perkembangan peserta didik, Bandung: Remaja Rosdakarya, 2009
[9] S. Sundari, Kesehatan mental dalam kehidupan, Jakarta: Rineka Cipta, 2005 .

[10] M. Fahmi, Kesehatan jiwa dalam keluarga, sekolah, dan masyarakat jilid I, Jakarta: Bulan Bintang, 2002.

[11] M. Ali, and M. Asrori, Psikologi remaja, Jakarta: Bumi Aksara, 2010.

[12] J. M. Bala, Hearing impaired students:adjusment, achievment motivation and academic achievment, New Delhi: Discovery Publishing House, 2007.

[13] Z. Accariya and M. Khalil, "The Socio-Emotional Adjustment of Learning-Disabled Students Undergoing School Transitions," Creative Education, vol. 07, no. 01, pp. 139-151, 2016.

[14] S. Bahgotra, A. K. Sharma, and B. Raina, "Psycho-Social Adjustment and Rehabilitation of The Blind," JK Science Sosial Medicine, vol. 10 no. 1,2008

[15] T. M. Anggriana, A. Kadafi, and R. P. Trisnani, "Peran konselor dalam meningkatkan keterampilan sosial siswa difabel," Prosiding Seminar Hasil Penelitian dan Pengabdian Kepada Masyarakat UNIPMA, Madiun: Universitas PGRI Madiun, pp. 146-151, 2017.

[16] N. Purwanto, Psikologi pendidikan, Bandung: Remaja Rosdakarya 2004.

[17] D. Lattu, "Peran guru bimbingan dan konseling pada sekolah penyelenggara pendidikan inklusi," Jurnal Bimbingan dan Konseling Terapan, vol. 2, no. 01, 2018.

[18] T. Trisnawati, I. Ibrahim, and A. Zaini, Upaya Guru BK dalam Membantu Penyesuaian Diri Peserta Didik Berkebutuhan Khusus di SMKN 4 Padang, Skripsi STKIP PGRI Sumatera Barat, 2014. 